\title{
Recommendations for the process of biomass and waste gasification in a rotary reactor
}

\author{
Izabella Maj ${ }^{1, *}$ and Piotr Ostrowski ${ }^{1}$ \\ ${ }^{1}$ SILESIAN UNIVERSITY OF TECHNOLOGY, Institute of Power Engineering and \\ Turbomachinery, Konarskiego 20, Gliwice, Poland
}

\begin{abstract}
The paper presents a technology for biomass and waste gasification/pyrolysis with use of flue gas as a converting agent. This technology includes a rotary reactor that operates continuously and is integrated with a power boiler, for example WR-25 type grate boiler. Process gas (syngas) as well as possible char being a result of the process are combustible and can be recirculated to the boiler's combustion chamber. The paper presents laboratory research of selected biomass and waste: Refuse derived fuel (RDF), wood chips, nut shells, sewage sludge, coal sludge, mixture of $50 \%$ coal sludge with $50 \%$ RDF. Basing on the laboratory research a calculation procedure was developed to determine an industrial-size process parameters. The procedure allows to calculate how much fuel can be gasified/converted in a rotary reactor and the reactor's dimension: inner diameter Dwr and length Lr.
\end{abstract}

\section{Introduction}

According to actual Polish law [1] it is forbidden to store waste that can be characterized by:

a) Total organic carbon (TOC) content above $5 \%$ of dry matter,

b) loss on ignition (LOI) above $8 \%$ of dry matter,

c) lower calorific value above $6 \mathrm{MJ} \mathrm{kg}$ of dry matter.

Under the current law regulations it is advisable to develop new technologies for waste thermal conversion. Thermal conversion of waste lead to the following benefits:

- conversion of waste chemical energy into heat and electricity,

- reduction of mass and volume of waste,

- reduction of landfills number,

- reduction of the sanitary and epidemiological danger,

- solid products of the process can be used for agricultural purposes.

Pyrolysis or gasification processes allow to reach following benefits without problems connected to direct waste combustion and co-combustion. Feeding boiler's combustion chamber with syngas (process gas, which is a result of gasification/pyrolysis process) significantly reduces slagging, fouling and high temperature corrosion of heated surfaces of the boiler. Moreover products of gasification and pyrolysis process can be accumulated and

\footnotetext{
* Corresponding author: izabella.maj@poslsl.pl
} 
used at another time or purpose, what is an advantage of these processes comparing with direct combustion.

Presented laboratory research and calculation procedure have been developed due to strong need for creating new technologies for waste and biomass thermal conversion. The aim of presented study is:

a) To assess the possibility of using flue gas as a converting agent for thermal conversion of alternative fuels (waste and biomass) and to recognize the usage of selected alternative fuels for thermal conversion in low temperature gasification/pyrolysis process witch use of flue gas as a converting agent,

b)To assess the influence of process temperature, fuel granulation and moisture content on syngas composition and the conversion rate of selected fuels,

c) To determine construction parameters for the rotary gasification reactor assuming that gasification/pyrolysis process is performed continuously in an industrial scale.

Research base on an idea of indirect co-combustion of waste and biomass in power boilers. The developed co-combustion technology was based on patent applications [2-5] and previous experience [6-12]. The solution claimed therein is presented on the diagram in Fig. 1. Flue gas flowing out from the combustion chamber -1 goes through the heat exchanger -9 and through the flue gas duct, from where it flows to the chimney. The installation for indirect co-firing of biomass consists of a reactor 15 supplied with a stream of shredded biomass in the feeder system - 13 and a stream of flue gas induced by the injector -10 . Flue gas is taken from the combustion air duct -8 by the stream of a working agent (water steam, compressed flue gas) supplied to the nozzle -12 by injector -10 . These flue gas enters the reactor -15 where the thermal treatment of biomass is made. The output of the flue gas injector -10 is adjusted to the process requirements by a control valve -7 built in the propeller duct -6 to the drive nozzle -12 . Flue gas flowing out from the reactor -15 with flammable gas products of the degradation process feeds the burners 3 and 4, and solid flammable and non-flammable products are transported through the lock -14 and possibly returned to the process.

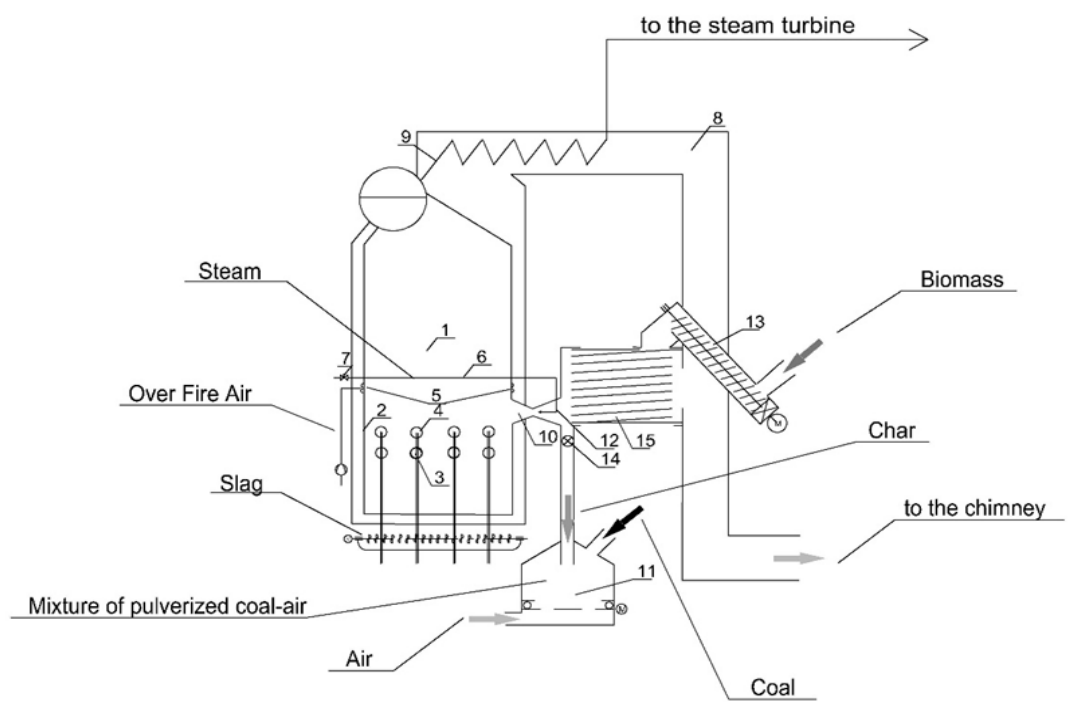

Fig. 1. Scheme of integration of power boiler with biomass and waste thermal treatment reactor 


\section{Experimental laboratory investigation}

Experimental laboratory research was conducted to develop design requirements and to identify the usability of the selected alternative fuels (biomass and waste fuels) for indirect co-firing in power boilers. Tests were conducted for following fuel types:

a) Refuse derived fuel (RDF)

b) Wood chips

c) Nut shells

d) Sewage sludge

e) Coal sludge,

f) Mixture of coal sludge 50\% witch RDF $50 \%$.

Tests were conducted in a laboratory gasification reactor designed and constructed specifically for this purpose. The experimental stand enables the weight loss of a sample and resulting gas composition to be recorded. The sample mass is approximately $3 \mathrm{~g}$, which distinguishes the method from the classic TGA method, which is frequently used for fuel thermal conversion investigations. Presented experimental setup enables to investigate gasification, pyrolysis, torrefecation and combustion, depending on agent composition and temperature requested. Measurement examples for gasification/pyrolysis process for mixture of coal sludge and RDF are presented in figures 2 and 3 and for RDF in figures 4 and 5. Experimental equipment allows to measure and record following parameters: Initial mass of the fuel sample, syngas composition $\left(\mathrm{O}_{2}, \mathrm{CO}_{2}, \mathrm{CO}, \mathrm{CH}_{4}, \mathrm{C}_{\mathrm{n}} \mathrm{H}_{\mathrm{m}}\right)$, process temperature and gas flow.

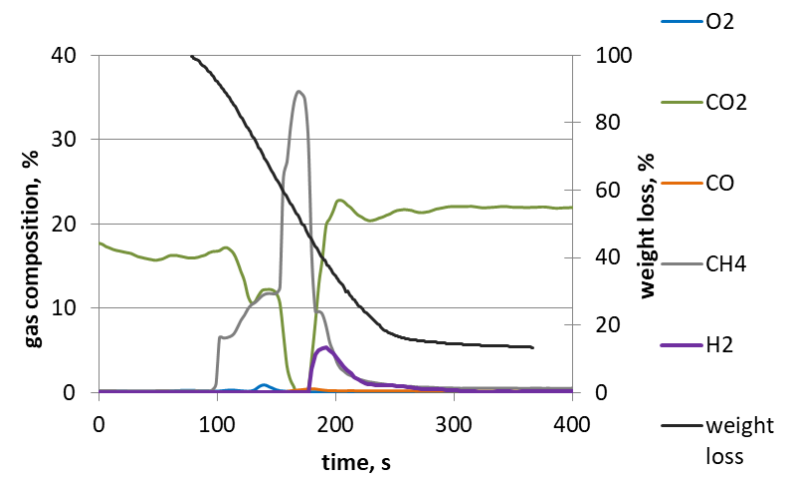

Fig. 2. Single measurement result for mixture of coal sludge and $\mathrm{RDF}$ in $750^{\circ} \mathrm{C}$

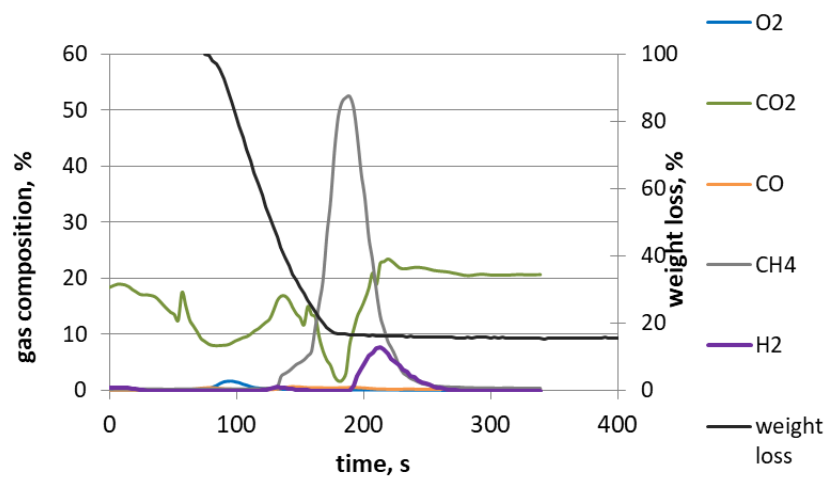

Fig. 3. Single measurement result for mixture of coal sludge and RDF in $850^{\circ} \mathrm{C}$ 


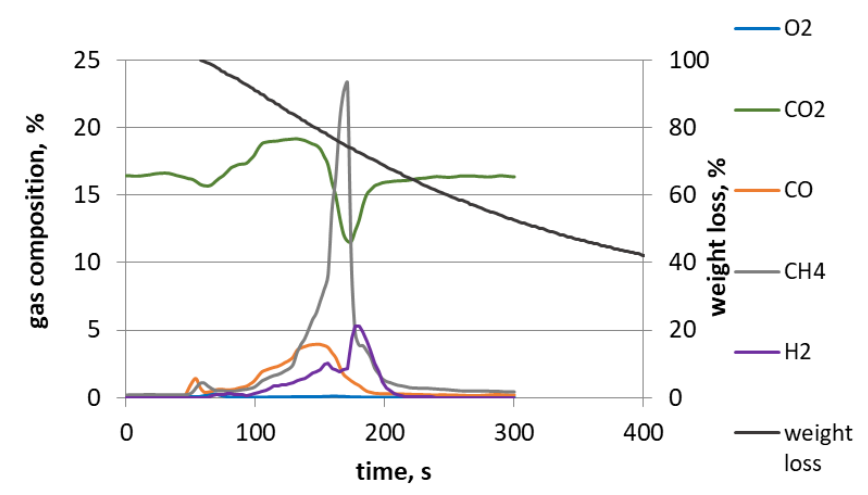

Fig. 4. Single measurement result for RDF in $650^{\circ} \mathrm{C}$

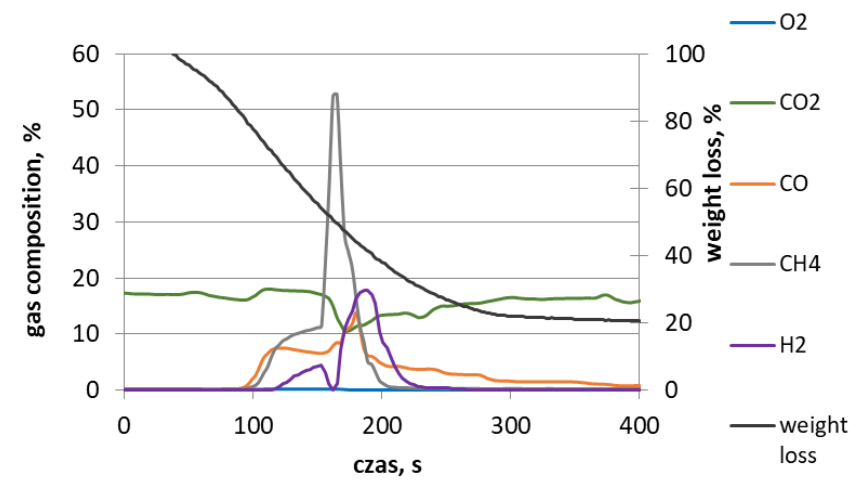

Fig. 5. Single measurement result for RDF in $850^{\circ} \mathrm{C}$

Tests were conducted in the temperature range of $350-850^{\circ} \mathrm{C}$ and with the application of dry and wet converting agents and for fuel in two states: as received and ground. It allows to identify the impact of the process temperature, the type of gasification agent and fuel granulation on the resulting gas (syngas) composition. Results of experimental gasification/pyrolysis process of RDF fuel are presented in Figures 6-9.

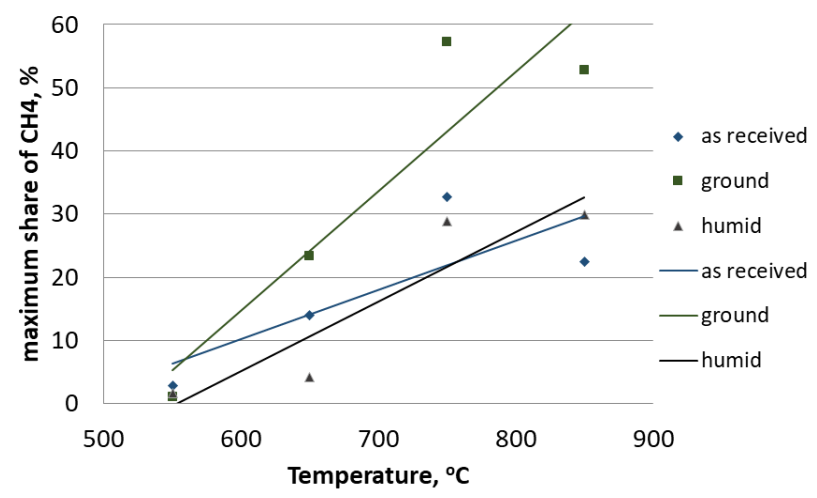

Fig. 6. Max share of $\mathrm{CH}_{4}$ in syngas for $\mathrm{RDF}$ 


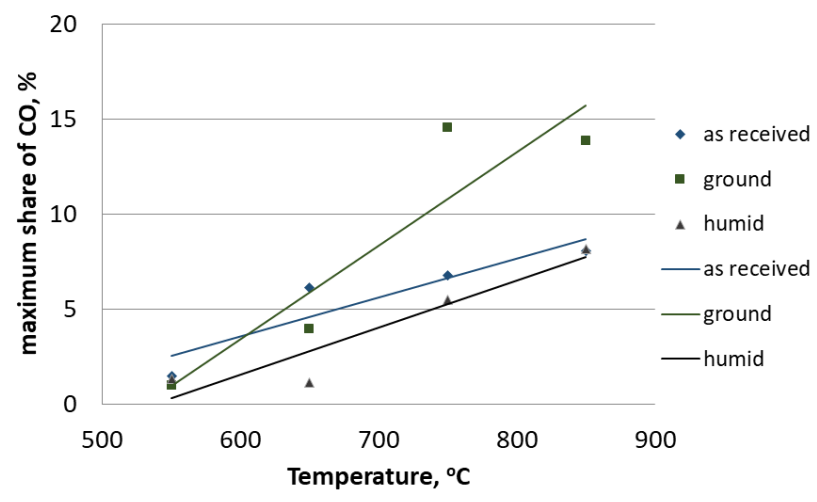

Fig. 7. Max share of CO in syngas for RDF

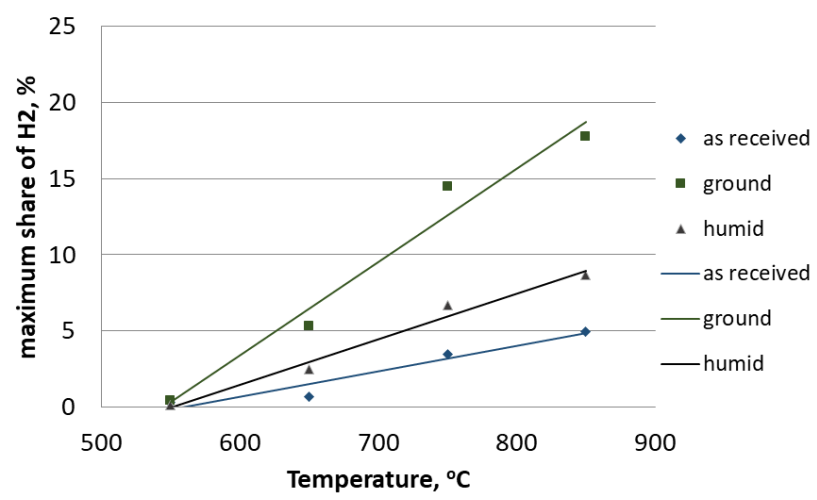

Fig. 8. Max share of $\mathrm{H}_{2}$ in syngas for $\mathrm{RDF}$

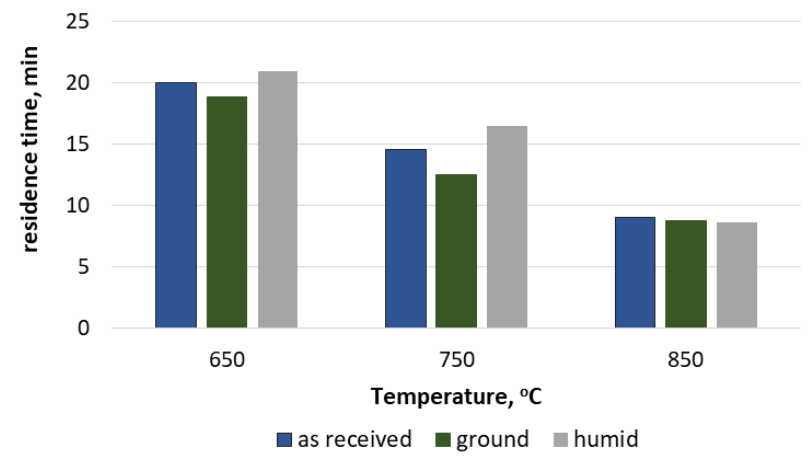

Fig. 9. Residence time for RDF

Final results of laboratory research are presented in Table 1. It includes maximum concentration of combustible components in syngas: $\mathrm{CO}_{\max }, \mathrm{CH}_{4 \max }, \mathrm{H}_{2 \max }$ and $\mathrm{C}_{\mathrm{n}} \mathrm{H}_{\operatorname{mmax}}$ ) and recommended residence time determined for each fuel. To determine the residence time a time constant value was used. Time constant in process dynamics is defined as a time of reaching $63 \%$ of new stable state. A fourth of time constant $4 \mathrm{~T}$ is claimed to be a time for new stable state of the process. 
Table 1. Recommended residence time and maximum concentration of syngas components for thermal conversion process of selected waste and biomass fuels

\begin{tabular}{|c|c|c|c|c|c|c|c|}
\hline \multirow{2}{*}{ Fuel } & \multirow{2}{*}{$\begin{array}{c}\text { Residence time/ } \\
\text { Syngas component }\end{array}$} & \multicolumn{6}{|c|}{ Process temperature, ${ }^{\circ} \mathrm{C}$} \\
\hline & & 350 & 450 & 550 & 650 & 750 & 850 \\
\hline \multirow{5}{*}{$\mathrm{RDF}$} & $4 \mathrm{~T}[\mathrm{~min}]$ & & & $\mathrm{X}$ & 18,8 & 12,5 & 8,6 \\
\hline & $\mathrm{CO}_{\max }[\%]$ & & & 1,48 & 6,12 & 14,56 & 13,84 \\
\hline & $\mathrm{CH}_{4 \max }[\%]$ & & & 2,83 & 23,34 & 57,26 & 52,77 \\
\hline & $\mathrm{H}_{2 \max }[\%]$ & & & 0,44 & 5,32 & 21,28 & 17,79 \\
\hline & $\mathrm{C}_{\mathrm{n}} \mathrm{H}_{\operatorname{mmax}}[\mathrm{ppm}]$ & & & 769 & 2281 & 6429 & 5156 \\
\hline \multirow{3}{*}{$\begin{array}{l}\text { Wood } \\
\text { chips }\end{array}$} & $4 \mathrm{~T}[\mathrm{~min}]$ & 24 & 7,6 & 4,3 & 3,9 & 2,0 & \\
\hline & $\mathrm{CO}_{\max }[\%]$ & 0,57 & 6,46 & 7,30 & 10,11 & 18,25 & \\
\hline & $\mathrm{CH}_{4 \max }[\%]$ & 0,12 & 1,40 & 1,44 & 2,36 & 4,41 & \\
\hline \multirow{3}{*}{$\begin{array}{l}\text { Nut } \\
\text { shells }\end{array}$} & $4 \mathrm{~T}[\mathrm{~min}]$ & 8,8 & 6,7 & 5,2 & 4,0 & 3,6 & \\
\hline & $\mathrm{CO}_{\max }[\%]$ & 4,12 & 6,74 & 8,03 & 12,59 & 15,05 & \\
\hline & $\mathrm{CH}_{4 \max }[\%]$ & 1,15 & 2,00 & 2,45 & 4,29 & 4,04 & \\
\hline \multirow{5}{*}{$\begin{array}{l}\text { Sewage } \\
\text { sludge }\end{array}$} & $4 \mathrm{~T}[\mathrm{~min}]$ & $\mathrm{X}$ & 37,6 & 33 & 17,9 & & \\
\hline & $\mathrm{CO}_{\max }[\%]$ & 2,06 & 3,55 & 6,07 & 6,66 & & \\
\hline & $\mathrm{CH}_{4 \max }[\%]$ & 0,80 & 1,38 & 1,01 & 2,15 & & \\
\hline & $\mathrm{H}_{2 \max }[\%]$ & 0,40 & 0,40 & 1,14 & 0,22 & & \\
\hline & $\mathrm{C}_{\mathrm{n}} \mathrm{H}_{\operatorname{mmax}}[\mathrm{ppm}]$ & 13 & 45 & 153 & 176 & & \\
\hline \multirow{5}{*}{$\begin{array}{l}\text { Coal } \\
\text { sludge }\end{array}$} & $4 \mathrm{~T}[\mathrm{~min}]$ & & & $\mathrm{X}$ & 37,6 & 33 & 17,9 \\
\hline & $\mathrm{CO}_{\max }[\%]$ & & & 0,1 & 0,62 & 1,65 & 2,53 \\
\hline & $\mathrm{CH}_{4 \max }[\%]$ & & & 3,33 & 11,84 & 19,81 & 20,84 \\
\hline & $\mathrm{H}_{2 \max }[\%]$ & & & 1,09 & 8,73 & 15,11 & 24,32 \\
\hline & $\mathrm{C}_{\mathrm{n}} \mathrm{H}_{\operatorname{mmax}}[\mathrm{ppm}$ & & & 20 & 61 & 111 & 103 \\
\hline \multirow{5}{*}{$\begin{array}{c}\text { Coal } \\
\text { sludge } \\
50 \% \\
+\mathrm{RDF} \\
50 \%\end{array}$} & $4 \mathrm{~T}[\mathrm{~min}]$ & & & & & 5,3 & 4,0 \\
\hline & $\mathrm{CO}_{\max }[\%]$ & & & & & 0,5 & 1,0 \\
\hline & $\mathrm{CH}_{4 \max }[\%]$ & & & & & 36,5 & 53,5 \\
\hline & $\mathrm{H}_{2 \max }[\%]$ & & & & & 5,0 & 8,0 \\
\hline & $\mathrm{C}_{\mathrm{n}} \mathrm{H}_{\operatorname{mmax}}[\mathrm{ppm}$ & & & & & $\mathrm{X}$ & $\mathrm{X}$ \\
\hline
\end{tabular}




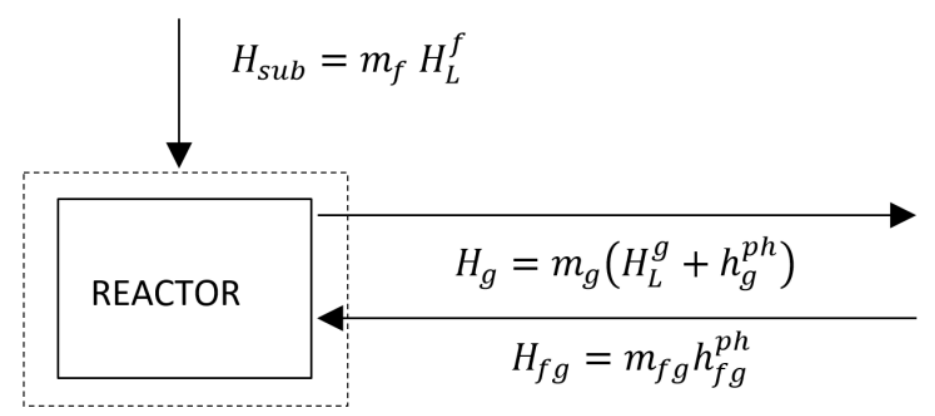

The balance sheet cover

Fig. 10. Thermal analysis model of gasification reactor

For thermal conversion of alternative fuels a mass and energy balance model was developed. Process efficiency (formula 5) and uncertainty was determined and presented below for RDF gasification in temperature $750^{\circ} \mathrm{C}$. Balance assumes that entire moisture takes part in reactions of $\mathrm{H}_{2}$ and $\mathrm{CH}_{4}$ forming so process gas is claimed to be dry $\left(\mathrm{H}_{2} \mathrm{O}\right)_{\mathrm{g}}=0$. Mass and Energy balance was determined for a single fuel sample.

Thermal analysis model of gasification/pyrolysis reactor is presented in Fig. 10.

$H_{i} \quad-$ Enthalpy of substrate/product

$m_{i} \quad-$ mass of substrate/product

$H_{L}^{i} \quad-$ lower heating value

$\mathrm{h}_{i}^{f} \quad-$ physical enthalpy

where i:

sub - substrate (waste/biomass)

$\mathrm{fg} \quad-$ flue gas

$g \quad-$ process gas

Mass balance for thermal conversion of single RDF sample in $750^{\circ} \mathrm{C}$ :

$$
m_{g}=m_{s u b}+m_{f g}
$$

$m_{g} \quad$ - mass of process gas

$m_{s u b}$ - mass of substrate (RDF sample)

$m_{f g}-$ mass of flue gas 
Enthalpy balance:

$$
H_{g}=H_{s u b}+H_{f g}
$$

where:

$$
\begin{aligned}
& H_{s u b}=m_{\text {sub }} H_{L}^{s u b} \\
& H_{L}^{s u b}=\Sigma\left(g_{j} H_{L}^{j}\right) \\
& H_{f g}=m_{f g} \mathrm{~h}_{f g}^{f} \\
& \mathrm{~h}_{f g}^{f}=\Sigma\left(\mathrm{r}_{l} \mathrm{~h}_{l}^{f}\right) \\
& H_{g}=m_{g}\left(H_{L}^{g}+\mathrm{h}_{g}^{f}\right) \\
& H_{L}^{g}=\Sigma\left(g_{k} H_{L}^{k}\right) \\
& \mathrm{h}_{g}^{f}=\Sigma\left(\mathrm{r}_{\mathrm{k}} \mathrm{h}_{k}^{f}\right)
\end{aligned}
$$

substrate chemical enthalpy,

lower heating value for gas with composition of $\Sigma g_{j}=1$,

flue gas enthalpy in temperature $t_{\mathrm{fg}}$,

specific enthalpy of flue gas with composition of $\Sigma g_{1}=1$, process gas enthalpy in temperature $t_{g p}$.

lower heating value of process gas with composition of $\Sigma g_{k}=1$, specific enthalpy of process gas with composition of $\Sigma r_{k}=1$

$$
\begin{array}{ll}
\text { finally } & m_{g}\left(H_{L}^{g}+\mathrm{h}_{g}^{f}\right)=m_{\text {sub }} H_{L}^{s u b}+m_{f g} \mathrm{~h}_{f g}^{f} \\
\text { and } & m_{g}=m_{\text {sub }}+m_{f g}
\end{array}
$$

Efficiency of thermal conversion process is defined as:

$$
\begin{gathered}
\eta=\frac{H_{g}}{H_{s u b}+H_{f g}} \\
\eta=\frac{m_{g}\left(H_{L}^{g}+\mathrm{h}_{g}^{f}\right)}{m_{\text {sub }} H_{L}^{s u b}+m_{f g} \mathrm{~h}_{f g}^{f}} \\
\eta=115,35 \%
\end{gathered}
$$

Efficiency of ideal thermal conversion process according to (2.5) is $100 \%$. Efficiency value higher than $100 \%$ is caused by an assumption that entire moisture takes part in reactions of $\mathrm{H}_{2}$ and $\mathrm{CH}_{4}$ forming, while chemical enthalpy of substrate (fuel) is defined as lower calorific value and does not consider fuel humidity.

Energy balance components for gasification of single RDF sample includes values presented in Table 2. 
Table 2. Energy balance components foe RDF gasification in $750^{\circ} \mathrm{C}$

\begin{tabular}{|c|c|c|c|}
\hline Parameter & Symbol & Unit & Value \\
\hline Temperature of flue gas & $\mathrm{t}_{\mathrm{fg}}$ & ${ }^{\circ} \mathrm{C}$ & 750 \\
\hline \multirow{3}{*}{ Specific enthalpy of syngas components } & $\mathrm{h}_{\mathrm{CO}_{2}}$ & $\mathrm{~kJ} / \mathrm{kg}$ & 787,6 \\
\hline & $h_{\mathrm{O}_{2}}$ & $\mathrm{~kJ} / \mathrm{kg}$ & 732,8 \\
\hline & $h_{N_{2}}$ & $\mathrm{~kJ} / \mathrm{kg}$ & 1103,0 \\
\hline Specific enthalpy of flue gas & $h_{s p}$ & $\mathrm{~kJ} / \mathrm{kg}$ & 1045,7 \\
\hline Mass of flue gas & $\mathrm{m}_{f g}$ & $\mathrm{~kg}$ & 0,001452 \\
\hline Enthalpy of flue gas & $\mathrm{H}_{f g}$ & $\mathrm{~kJ}$ & 1,5184 \\
\hline Mass of substrate (RDF) & $\mathrm{m}_{\text {sub }}$ & $\mathrm{kg}$ & 0,0034 \\
\hline Lower heating value of substrate (RDF) & $H_{L}^{s u b}$ & $\mathrm{~kJ} / \mathrm{kg}$ & 15200 \\
\hline Chemical enthalpy of substrate (RDF) & $H_{s u b}$ & $\mathrm{~kJ}$ & 51,68 \\
\hline Temperature of syngas & $\mathrm{tg}_{\mathrm{g}}$ & ${ }^{\circ} \mathrm{C}$ & 750 \\
\hline \multirow{6}{*}{ Specific enthalpy of syngas components } & $h_{\mathrm{CH}_{4-} \mathrm{g}}$ & $\mathrm{kJ} / \mathrm{kg}$ & 2503 \\
\hline & $\mathrm{h}_{C O \_g}$ & $\mathrm{~kJ} / \mathrm{kg}$ & 1047 \\
\hline & $h_{H_{2}-g}$ & $\mathrm{~kJ} / \mathrm{kg}$ & 1452,2 \\
\hline & $h_{\mathrm{CO}_{2-} \mathrm{g}}$ & $\mathrm{kJ} / \mathrm{kg}$ & 787,6 \\
\hline & $h_{O_{2-} g}$ & $\mathrm{~kJ} / \mathrm{kg}$ & 732,8 \\
\hline & $h_{N_{2}-g}$ & $\mathrm{~kJ} / \mathrm{kg}$ & 1103 \\
\hline Enthalpy of syngas & $\mathrm{h}_{g}$ & $\mathrm{~kJ} / \mathrm{kg}$ & 1154,96 \\
\hline Mass of syngas & $\mathrm{m}_{g}$ & $\mathrm{~kg}$ & 0,004852 \\
\hline Lower heating value of syngas & $H_{L}^{g}$ & $\mathrm{~kJ} / \mathrm{m}^{3}$ & 3550,427 \\
\hline Physical enthalpy of syngas & $\mathrm{H}_{g}^{f}$ & $\mathrm{~kJ}$ & 5,604 \\
\hline Chemical enthalpy of syngas & $\mathrm{H}_{g}^{c h}$ & $\mathrm{~kJ}$ & 55,76322 \\
\hline Total enthalpy of syngas & $\mathrm{H}_{g}^{c}$ & $\mathrm{~kJ}$ & 61,36727 \\
\hline
\end{tabular}


Uncertainty of gasification/pyrolysis efficiency calculation:

For process efficiency according to formula 2.6 an uncertainty was determined. Uncertainty takes into account single components' uncertainties according to table 3 and enthalpy values $H_{s u b} ; H_{s p} ; H_{g p}$ according to table 2 .

Table 3. Process components uncertainties

\begin{tabular}{|c|c|c|c|c|}
\hline & $\begin{array}{c}\text { Parameter/measuring } \\
\text { equipment }\end{array}$ & Manufacturer & $\begin{array}{c}\text { Number of } \\
\text { variables }\end{array}$ & $\begin{array}{c}\text { Uncertainty of gas } \\
\text { component measurement }\end{array}$ \\
\hline 1 & Process gas analyzer & Gasboard-3100P & 6 & $\begin{array}{c}\text { Heteroatomic gases 2\% } \\
\text { Monoatomic gases 3\% }\end{array}$ \\
\hline & $\begin{array}{c}\text { Lower heating value of } \\
\text { process gas }\end{array}$ & Gasboard-3100P & 6 & $5,38 \%$ \\
\hline 2 & Flue gas analyzer & Gasboard-3100P & 4 & $2 \%$ \\
\hline 3 & $\begin{array}{c}\text { Lower heating value of } \\
\text { substrate (fuel) }\end{array}$ & analytical method & & $5,33 \%$ \\
\hline 4. & Gas flow meter & M+W Electronics & & $0,51 \%$ \\
\hline 5. & Scales & Radwag & & $3 \%$ \\
\hline
\end{tabular}

Finally the uncertainty of RFD gasification/pyrolysis efficiency determination is calculated:

$$
\frac{\Delta \eta}{\eta}= \pm 36,67 \%
$$

And process efficiency can be presented as:

$$
\eta=115,35 \% \pm 36,76 \%
$$




\section{Directions for industrial-scale gasification/pyrolysis process}

Basing on the laboratory research results a calculation procedure was developed. In allows to determine the syngas flow and composition as well as reactor's dimensions and operating parameters. Procedure includes stages as presented in Figure 11.

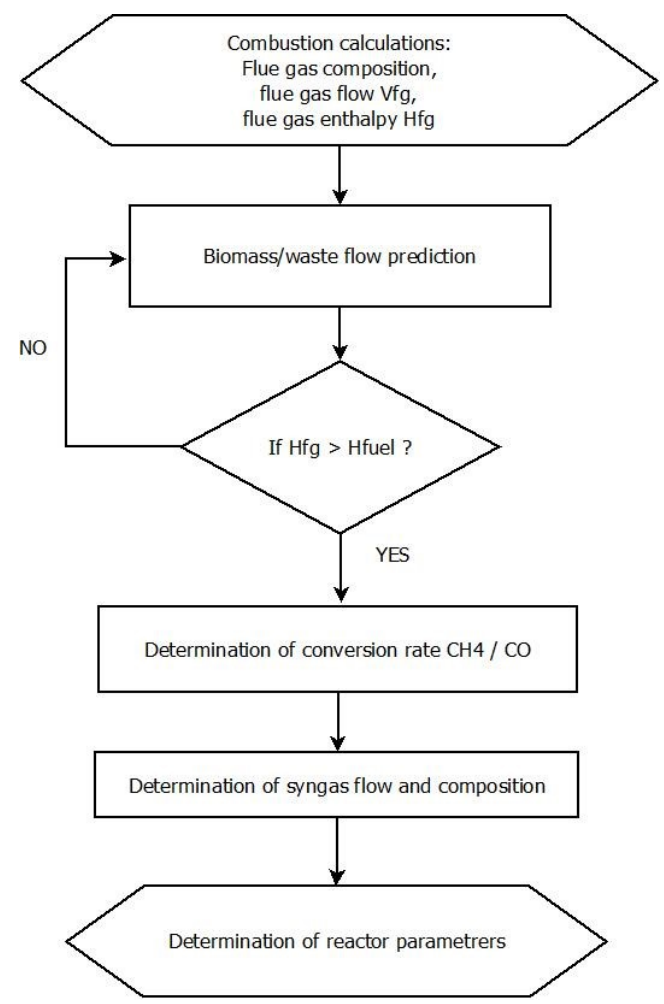

Fig. 11. Stages of calculation procedure

As an example of calculations a model of integrating the reactor with WR-25 boiler is presented in table 4. Reactor's parameters are defined in Figure 12.

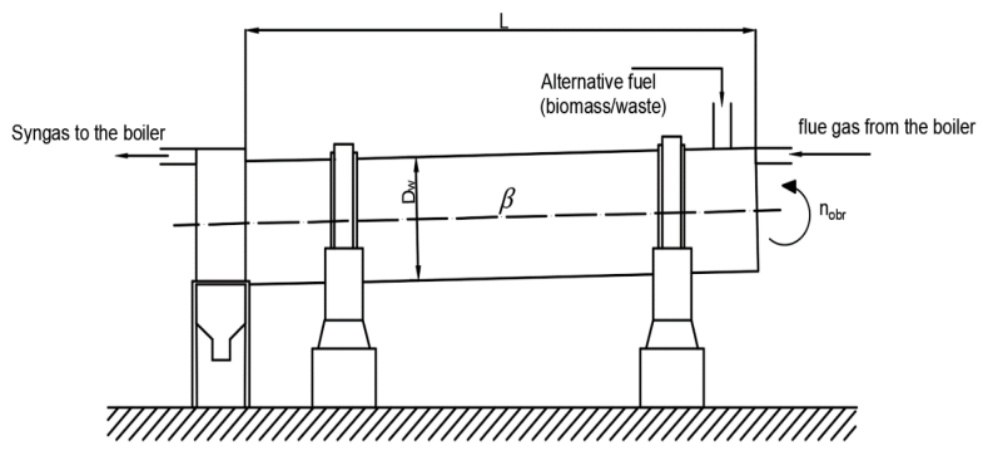

Fig. 12. Rotary reactor scheme 
Table 4. Reactor parameters for integration of gasification/pyrolysis reactor with WR-25 boiler

\begin{tabular}{|c|c|c|c|}
\hline Parameter & Symbol & Value & Unit \\
\hline Fuel flow & $\dot{m}_{s u b}$ & 397,9 & $\mathrm{~kg} / \mathrm{h}$ \\
\hline Residence time & $\tau_{\mathrm{p}}$ & 516 & $\mathrm{~s}$ \\
\hline Reactor diameter & $\mathrm{D}_{\mathrm{wr}}$ & 1,424 & $\mathrm{~m}$ \\
\hline Reactor lenght & $\mathrm{L}_{\mathrm{r}}$ & 4,807 & $\mathrm{~m}$ \\
\hline L/D ratio & $\mathrm{L}_{\mathrm{r}} / \mathrm{D}_{\mathrm{wr}}$ & 3,376 & - \\
\hline Revolutions per minute & $\mathrm{n}_{\mathrm{obr}}$ & 1 (with regulation range & $\mathrm{rpm}$ \\
\hline Reactor's axis lean & $\beta$ & 16 & $\circ$ \\
\hline Gas velocity (inside the reactor) & $\mathrm{vg}$ & 0,5 & $\mathrm{~m} / \mathrm{s}$ \\
\hline
\end{tabular}

Presented calculations assume $6 \%$ oxygen share in flue gas. It takes into account that $2,5 \%$ of flue gas from WR-25 boiler is provided to the gasification reactor. Enthalpy of flue gas allows thermal conversion of $397,9 \mathrm{~kg} / \mathrm{h}$ (9,55 tones per day) of RDF fuel. Presented calculation was conducted for each of tested fuel having regard three oxygen concentration levels: $6 \%, 8 \%$ and $10 \%$, which are typical for grate boilers. Total oxygen in assumed to take part in partial combustion taking part in the reactor. Results summary are presented in Table 5.

Table 5. Operating parameters for gasification/pyrolysis process in the rotary reactor

\begin{tabular}{|c|c|c|c|c|}
\hline \multirow{3}{*}{ Fuel type } & \multirow{3}{*}{$\begin{array}{l}\text { Concentration of } \mathrm{O}_{2} \\
\text { in flue gas }\end{array}$} & \multirow{2}{*}{$\frac{\text { Fuel flow }}{\dot{m}_{s u b}}$} & \multicolumn{2}{|c|}{ Dimensions of the reactor } \\
\hline & & & $\mathrm{D}_{\mathrm{wr}}$ & $\mathrm{L}_{\mathrm{r}}$ \\
\hline & & $\mathrm{kg} / \mathrm{h}$ & $\mathrm{m}$ & $\mathrm{m}$ \\
\hline \multirow{3}{*}{ RDF } & $6 \%$ & 397,9 & 1,424 & 4,807 \\
\hline & $8 \%$ & 703,8 & 1,601 & 5,404 \\
\hline & $10 \%$ & 1142,0 & 1,821 & 6,145 \\
\hline \multirow{3}{*}{ Wood chips } & $6 \%$ & 370,1 & 1,414 & 1,053 \\
\hline & $8 \%$ & 665,4 & 1,584 & 1,179 \\
\hline & $10 \%$ & 1078,5 & 1,796 & 1,337 \\
\hline \multirow{3}{*}{ Nut shells } & $6 \%$ & 430,6 & 1,427 & 1,912 \\
\hline & $8 \%$ & 774,3 & 1,605 & 2,151 \\
\hline & $10 \%$ & 1256,5 & 1,826 & 2,447 \\
\hline \multirow{3}{*}{ Sewage sludge } & $6 \%$ & 412,7 & 1,423 & 6,351 \\
\hline & $8 \%$ & 741,8 & 1,599 & 7,142 \\
\hline & $10 \%$ & 1203,0 & 1,817 & 8,115 \\
\hline \multirow{3}{*}{ Coal sludge } & $6 \%$ & 295,5 & 1,397 & 9,311 \\
\hline & $8 \%$ & 502,6 & 1,594 & 10,618 \\
\hline & $10 \%$ & 812,2 & 1,813 & 12,077 \\
\hline \multirow{3}{*}{$\begin{array}{l}\text { Coal sludge } 50 \% \\
\quad+\text { RDF } 50 \%\end{array}$} & $6 \%$ & 318,3 & 1,440 & 2,143 \\
\hline & $8 \%$ & 565,4 & 1,631 & 2,429 \\
\hline & $10 \%$ & 912,2 & 1,867 & 2,780 \\
\hline
\end{tabular}




\section{Law principles of syngas combustion and co-combustion}

The technology of indirect co-combustion of waste through the integration of a gasification reactor with a power boiler does not require the construction of a new thermal waste facility. It can be based on a local waste management facility, which ensures continuous supply of waste and local boiler house or energy company that provide the possibility of integrating the reactor with its boiler. The implementation of gasification technology is therefore cheaper than the construction of a new waste combustion facility. In addition, it is not associated with any objections from the local community [13].

The Industrial Emissions Directive of European Commission [14] distinguishes gasification and pyrolysis of waste from combustion. Article 42 of the Directive indicates that special requirements for thermal treatment of waste do not apply to gasification or pyrolysis installations. It provides that if the syngas from these thermal processes is purified such it does not cause emissions bigger than combustion of natural gas it is no longer threatened as waste combustion. This rule was implemented in September 2014 into Polish legislation [15]. According with the requirements of the Directive, combustion of syngas from gasification of waste should meet the emission requirements for natural gas. They are defined in the following standards: PN-C-04752: 2011 and PN-C-04753:2011. Meeting this requirements for syngas combustion allows to omit the technical requirements set by the Regulation of the Development Ministry ("waste regulation") [16] regarding the waste thermal treatment conditions:

- Flue gas temperature from higher than $850^{\circ} \mathrm{C}$ in no less than 2 seconds and

- The total organic carbon content (TOC) in slags and ash less than $3 \%$ mass, or loss of ignition (LOI) for slags and lower than $5 \%$ on dry matter.

Moreover there is no need to apply emission standards provided for waste combustion and co-combustion. When purified syngas is combusted the power unit should comply with emission standards for natural gas combustion in energy facilities.

These principles allow to significantly increase the applicability of waste gasification and pyrolysis technologies. These technologies enable thermal utilization of municipal and industrial waste in most types and sizes of boilers in local, industrial or professional facilities.

\section{Summary}

The paper presents results of the investigation of an innovative biomass and alternative fuel low-temperature gasification method before co-firing in industrial or power plant boilers. As a first step before conducting industrial-scale process laboratory research was carried out to investigate usability of selected fuels to low-temperature gasification/pyrolysis. This process may take place in temperature ranging from $350{ }^{\circ} \mathrm{C}$. Laboratory research was conducted in a reactor designed and constructed for a thermal conversion of 1-3 g mass sample. The experimental stand enables the use of flue gas-alike gas mixture as a gasifying agent and on-line measuring of the weight loss of a sample and syngas composition. The aim of presented laboratory research was to assess the usability of selected biomass fuel for indirect co-firing in power boilers and to build a knowledge base for industrial-size process. Investigated parameters were: gasification kinetics (recommended time for total gasification), preferred fuel granulation and most favorable process temperature. Basing on laboratory results a calculation procedure was developed to determine parameters for industrial-size process. It assumes a rotary reactor that operates continuously and is connected to a grate boiler WR-25. Presented method of in-direct co-combustion of waste 
and biomass can be a part of local waste management or an element of renewable energy sources system.

\section{References}

1. Rozporządzenie Ministra Środowiska z dnia 9 grudnia 2014 r. w sprawie katalogu odpadów. Dziennik Ustaw Rzeczypospolitej Polskiej 2014 poz. 1923 (2014)

2. P. Ostrowski, M. Pronobis, S. Kalisz., F. Gramatyka, R. Wejkowski: Patent PL212497 Method and installation of biomass pyrolysis prior to cofiring, in particular in power boilers (2008)

3. P. Ostrowski, M. Pronobis, S. Kalisz, F. Gramatyka, R. Wejkowski, Patent PL212557 Method and installation of carbonisation and biomass gasification prior to cofiring, in particular in power boilers (2008)

4. P. Ostrowski, M. Pronobis, S. Kalisz, F. Gramatyka, R. Wejkowski: Patent PL214645 Method and installation of biomass gasification prior to cofiring, in particular in power boilers (2008)

5. P. Ostrowski, M. Pronobis, S. Kalisz, R. Wejkowski, Remiorz L.: Patent application P393836 Method of measuring and gas stream meter in short closed ducts of large cross-section area, in particular in air and flue gases boiler and ventilation circuits, (2013)

6. P. Ostrowski, I. Maj, S. Kalisz, M. Polok.: Biomass low-temperature gasification in a rotary reactor prior to cofiring of syngas in power boilers. Appl. Therm. Eng. 118, 785-795 (2017)

7. P. Ostrowski, Innovative measuring techniques and technologies in modernisation of energy and industrial installations and equipment (in Polish). Monograph of Silesian University of Technology, (2014)

8. R. Litka, S. Kalisz, Thermochemical analysis of a flue gas-driven biomass gasification. Chem. and Process Eng., 33, 487-503. (2012)

9. P. Ostrowski, L. Remiorz, Measurement of gas flow in short ducts, also rectangular, Elsevier Editorial System Flow Measurement and Instrumentation, 49, 301-311 (2011)

10. P. Ostrowski, I. Maj, S. Kalisz, M. Polok: Testing of an innovative installation for alternative fuel low-temperature gasification prior to co-firing in power boilers. Procedia Eng. 174, 1877-7058, (2017)

11. I. Maj, E. Kudlek, P. Ostrowski, M. Pronobis: Investigation of sewage sludge gasification with use of flue gas as a gasifying agent. E3S Web of Conferences 14 2267-1242 (2016)

12. I. Maj: Badanie kinetyki zgaozwania wybranych paliw alternatywnych oraz zalecenia dla eksploatacji przykottowych instalacji zgazowania. $\mathrm{PhD}$ Thesis, Silesian University of Technology (2018)

13. W. Nikodem: Zgazowanie odpadów komunalnych, Polityka energetyczna, 10, (2007)

14. Directive 2010/75/EU of the European Parliament and of the Council of 24 November 2010 on industrial emissions (integrated pollution prevention and control) (2010)

15. Ustawa o odpadach z dnia 14 grudnia 2012 roku (tekst jednolity Dz.U. z 2016, poz. 1987 (2016)

16. Rozporządzenie Ministra Rozwoju z dnia 21 stycznia 2016 r. w sprawie wymagań dotyczących prowadzenia procesu termicznego przekształcania odpadów oraz sposobów postępowania $\mathrm{z}$ odpadami powstałymi w wyniku tego procesu. Dziennik Ustaw 2016 poz. 108 (2016) 